\title{
Thinking and Exploration of Building "Iron-making" Course System
}

\author{
Gui Yongliang, Hu Binsheng , Hu Changqing \\ (Hebei United University ，College of Metallurgy and Energy, Tangshan, China 063009)
}

\begin{abstract}
In view of the the characteristics of metallurgical engineering " iron-making " teaching content closely combined with production practice, puts forward building "course system of iron-making "which aims to break the boundaries between the four courses of " iron-making " teaching content.At the same time of strengthening theory teaching, emphasizing the part of practical teaching, improving teaching methods and teaching means, making video and animation teaching material of production locale, building a high level teaching faculty, in order to improve the teaching level and teaching quality of metallurgical engineering undergraduate.

Keywords-metallurgical engineering; iron-making; course system
\end{abstract}

\section{INTRODUCTION}

Metallurgical engineering of Hebei United University is the key discipline of national characteristic specialty and the provincial outstanding key discipline, which is the only one that has a bachelor's, master's and doctorate in multi-level training ability of metallurgical discipline in Hebei province and a national comprehensive reform pilot. It has trained more than 5000 professional and technical personnel and project management personnel for metallurgical industry in the past 55 years. The three professional basic courses of metallurgical engineering that "metallurgy transmission principle", "metallography" and "metallurgical principle" gradually became a provincial excellent course in recent years. In 2010, one of metallurgy engineering professional backbone courses "steel-making " course integrates the four programs in steelmaking, declare the excellent course at the provincial level. However, because of iron-making aspects between the four major courses of the content of the bridging degree is insufficient, logical relationship is not strong, make "iron" curriculum system has not been established. In order to improve the teaching quality of metallurgical engineering majors, broaden the teaching resources and teaching means, build a high level of teacher team and curriculum teaching team, it is neccessry for metallurgical engineering professional backbone course "iron-making" to build a curriculum system.

\section{CONST RUCTION GOAL OF “IRON-MAKING”COURSE SYSTEM}

"Iron-making" is one of the main core production technology of the metallurgical process, which is a discipline of the application of physical and chemical disciplines basic theory and research method to extract the metallurgical process and a bridge and the link of basic theory connected with professional production practice, as well as a guidelines and tools of understanding of the existing production technology and process flow and setting up a new technology and process flow. "Iron-making " course is one of the professional backbone course of metallurgical engineering, the main contents include iron-making raw material, the principle of iron-making, iron-making operation, iron-making equipment and design, aided process etc, involving the "iron and steel metallurgy I ", "iron-making design principle" and "blast furnace coal injection", "non-blast furnace iron-making" four courses. The goal of building "iron-making" course system is to use various forms of teaching methods and teaching means and combine the four courses, pay attention to in the process of teaching course cross between fusion, logical cohesion and mutual penetration, and combining with the actual production of the iron-making process, to produce a video and animation teaching material, with experimental teaching and practice. 
Theory teaching mainly through the teaching of iron ore powder building blocks, the blast furnace smelting process of physical chemistry, transport phenomena and energy utilization, blast furnace iron-making technology, blast furnace, blast furnace coal injection workshop equipment, iron-making workshop design, basic principle and process of blast furnace iron-making, etc, make the students master process of blast furnace iron-making process and theory, to cultivate students by using the basic theory of learning ability to analyze and solve practical problems of iron-making process. Through the study of theory course, master the theoretical foundation and workshop design, etc of sintering pellets, blast furnace iron-making, pulverized coal injection technology.

Experiment teaching based on our school's metallurgical engineering experiment center, the center is equipped with a full-time experimentalist responsible for equipment maintenance, and participate in the practice teaching. Combined with theoretical teaching, cultivate students ability to analyze and solve problems, make students accept basic training of metallurgical experimental techniques, master the main methods of metallurgical experimental research, verify and supplement the content of the theory lessons, for trains the student's theory and practice foundation to participate in the design and operation of metallurgical engineering research, strengthen students' ability to solve problems.

Cognition practice and production practice is the student experience the scene of the production process, will have a great impact on the course of "iron-making" .Through all processes of iron-making process of practical observation, inquiry, technical workers and teachers' introduction and the answer, students will have more in-depth knowledge of production technology and equipment, it is very helpful for the theory teaching. In theory teaching process, teachers will combine the book concept, theory with the technology, can greatly improve the efficiency of students to master knowledge.

\section{THINKING OF BUILDING “IRON-MAKING”COURSE} SYSTEM

\section{A. Construction of Teachers Team}

In line with the teaching and scientific research, combining teachers structure, the combination of theory teaching and practice teaching, combining the principle of combining undergraduate teaching and graduate teaching, aimed at young and middle-aged and young backbone teachers' professional competence and actual needs, adjust the course group teaching force. At the same time, the highlight of the curriculum of iron-making production practice and engineering application background, training teachers' selective to iron and steel enterprises, the introduction of experienced engineers to the platform, improve the level of teaching team of teaching. Combined with the platform to build research center and by building enterprise regularly provide appropriate jobs for school teachers on secondment or field exercise, participate in project research and development and technological innovation of an iron and steel enterprise, familiar with the production of the enterprise management, not only can solve enterprise technical problem, but also can cultivate and enhance teachers' practice ability, can also be the latest production technology and advanced management concept to enrich teaching contents, improving teaching quality. In the current enterprises adjunct profes sor help guide practice, "outstanding engineers classroom", on the basis of the implementation of the "outstanding engineers into course group", adjunct professor should be brought into the teacher's teaching research of management series, accord ing to the nature of the course is combined with full-time and part-time job principle, reconstruct academic staff echelon, teaching the integration of the curriculum group. The implementation of the measures not only can bring the latest technology methods and scientific research achievements into classroom, make the classroom environment more close to the industry, close to the iron and steel enterprises, close to the demand, but also can be done by full-time teachers and part-time teachers share the teaching task and teaching research activities, improve experience in engineering practice of professional teachers. 


\section{B. Teaching Methods and Teaching Means}

Improve teaching methods and classroom teaching environment and atmosphere. In the teaching process, highlight the advantages of discussion-based teaching, inquiry teaching, case teaching method and so on various teaching methods, according to the characteristics of the course in the teaching content, use a variety of teaching methods to design good each lesson teaching. Combining various types of steel enterprises in the actual production data with teaching contents, lets the student feel learning content is no longer a dull, so as to improve the students' study enthusiasm. Adhere to the basic purpose of being based on the students and differential treatment in education. The teacher prepares a lesson carefully, through the guide, questions, enlightenment, stimulate students' learning interest and eager for knowledge. In order to use inductive thinking mode, start from the perception, raise the question constantly, inspire the student thinking. Speak out the emphasis and difficulty on the basis of speaking clear train of thought. It is also Interspersed a discussed summary type teaching method in the teaching of the course. Teachers set the topic carefully, carefully organize, Timely guide in the discussion and encourage students' insights and divergent thinking, finally take a penetrating summary by teachers.

$\mathrm{W}$ ith the aid of multimedia, video and animation teaching, develop a advanced teaching means of combining of various forms. Aiming at the characteristics of iron-making course closely combined with production, develop multimedia and animation teaching material e, Video to the production of iron and steel enterprises. For the strong logicality, formula deduction more chapters, use traditional blackboard writing teaching and improve the students' thinking ability. As to abstract concept and complex content sections, with the help of the advanced teaching means such as audio, video, show students more intuitive knowledge of iron-making, arouse and cultivate students' interest in professional course learning. Curriculum group is conducting "iron-making " course teaching website construction and integrating the abundant teaching resources on the site, which not only provides teachers opportunities of generalizations, constantly explore, also provide $\mathrm{s}$ a better hardware environment for the students to obtain richer and more comprehensive course information, convenient for students' autonomous learning. Therefore, in the course construction, in addition to the teacher answer questions stipulated time every week, it will also open the teachers' answering questions on the net, which not only solve the problems of students, also can be further widen teachers' teaching ideas, enrich knowledge, and truly teaching is learning .

\section{Practical Teaching Link}

During the process of classroom teaching, pay attention to the connection of metallurg ical engineering practice, the concrete of iron-making production and vivid animation material through each unit operation in theory teaching. To penetrate the teachers' rich scientific research practice in theory teaching, timely carry out "heuristic" and "discussion-based" teaching, cultivating students' good habits of thinking, osmosis sets up the engineering consciousness, through the examples and exercises to strengthen engineering point of view, to carry out the recitation discussion-based teaching. Such as in the teaching of the blast furnace smelt ing process chapter, first of all let us watch the blast furnace smelting process, make the students understand the main equipment of the iron-making, the basic process and the basic principle of iron-making. When introduced the blast furnace coal injection technology, complement with the scientific research work of the specific research result, and combine with the characteristics of bituminous coal, anthracite and other types to make students realize the modern theory of mixed coal injection of blast furnace selection basis.

Open experiment teaching process, in addition to the verification experiment, also increase opened the comprehensive, designing experiments and chosen to do experiments. This shows both the students' practical and hands-on ability, also improve the students' ability of finding problem, analyzing and solving problems, through the experimental process and experiment report summary, greatly improving the students' solidarity and collaboration and the ability to communicate with each other, improve the students' writing level of science and technology. 
Through the experiment of different forms to make the students to enhance the understanding of theoretical knowledge, improve the practical ability and make the students fully understand iron-making production process by recognizing practice and production practice, increase the perceptual knowledge, strengthen the engineering consciousness, set up a "bridge" from schools to factories, from theory to practice for the students. Combined with metallurgy laboratory research methods course learning and professional curriculum design, undertake to the students' cultivation of modern engineering design idea and design methods, cultivate students' comprehensive ability of application of various aspects of knowledge and skills to solve engineering problems, the original experience design to optimize design, to expand the past process and equipment validation into continuous design of process design, equipment calibration, economic evaluation, and draw the flow chart of process equipment, Really make students get engineering design integrated exercise.

D. the Teaching Management

"Iron-making" teaching pay attention to communication after class, the email answer and QQ group communication method of teaching. Make sure the communication of teachers and students' knowledge and teaching methods. Make sure teachers grasp the students learning situation communication, solve the problems and difficulties in students' learning, understand the teaching effect and deficiency, improve teaching methods and content, benefit to students summarize and understand dynamic course, improve the quality of teaching.

Previous assessments are relying on the final exam to evaluate students' learning situation. In the face of quality education, social needs of cultivating high-quality innovative talents, it must reform the exam-oriented education model, emphasize and strengthen the cultivation of students' comprehensive ability. The final grade is divided into two parts that grades plus test scores. Grades account for $20 \% \sim 30 \%$, mainly including learning attitude, class attendance, answering questions, learning initiative, finish the homework, etc.; Knot class exam accounted for $70 \%$ 80\%; For many years, the group always adhere to the objective evaluation of teaching effect, the thesis takes the form of A, B, A variety of questions, to increase the coverage, unified proposition, unified exam and unified marking system. Teaching practice shows that it has a promoting effect on the teachers and students after the reform of assessment method. It is helpful to the improvement of teaching level and teaching effect.

\section{CONCLUSION}

By building "iron-making" course system of metallurgical engineering, make the course more advanced on education teaching idea, curriculu m system and teaching content can reflect basic, advanced and applied, teaching methods and teaching means keep pace with the times. After two terms of metallurgical engineering undergraduate teaching practice, it can cultivate the students' thinking ability, the engineering application ability and innovation consciousness, comprehensively improve the quality of teaching. Taken building "iron-making " course system as an opportunity to build a high level of teaching team, greatly improve the basic quality of teachers and teaching level. At the same time, the effect and experience of the course system for the construction and reform of other courses play a de monstration role, drive the develop ment of other disciplines and other metallurgical engineering specialty colleges education teaching reform project, to improve the quality of undergraduate teaching has an obvious role in promoting.

\section{REFERENCES}

[1] Rongjie He. Education Technology, Information Technology and Curriculum Integration [J]. Journal of Modern Educational Technology, 2010, $20(10): 41-43$

[2] Yong Lu, Xiuqin Pan, Yue Zhao, etc. National Colleges and Universities of Applied Automation Professional Curriculum System Construction Research [J]. Journal of China Science and Technology Information $2010(22): 245-246$

[3] Ning Fu. Aviation Meteorological Practice Teaching Reform and Curriculum System Construction [J]. Journal of Xi'an Aerotechnical College, 2010, 28(6) :37-39 